Article

\title{
Brand Awareness in the Context of Mistrust: The Case Study of an Employment Agency
}

\author{
Kristina Ročkute ${ }^{1}$, Inga Minelgaite ${ }^{2}$, Ligita Zailskaitė-Jakšte ${ }^{3}$ and Robertas Damaševičius ${ }^{4, *}$ (i) \\ 1 Independent consultant, 07101 Vilnius, Lithuania; kristinaroc@gmail.com \\ 2 School of Business, University of Iceland, 101 Reykjavik, Iceland; inga.minelgaite@gmail.com \\ 3 Department of Multimedia Engineering, Kaunas University of Technology, 44249 Kaunas, Lithuania; \\ ligita.zailskaite@ktu.lt \\ 4 Department of Software Engineering, Kaunas University of Technology, 44249 Kaunas, Lithuania \\ * Correspondence: robertas.damasevicius@ktu.lt; Tel.: +370-37-300353
}

Received: 5 January 2018; Accepted: 27 February 2018; Published: 5 March 2018

\begin{abstract}
Brand awareness is important for a good market performance of a company. However, research on the contextual preconditions needed for the improvement of brand awareness is limited, particularly in specific service sectors such as employment agencies. We present the research results of the preconditions for the improvement of awareness (which is one of the dimensions of brand equity) in an employment agency. We also analyze the effects of the perceived trust of customers on the improvement of brand awareness in the employment sector. As a case study, we present an example of an employment agency in Lithuania. This research is particularly timely in the Lithuanian context, where high levels of emigration are having a considerable negative impact on companies and their major internal operations-human resource management, marketing, and strategic planning-challenging the aims of long-term socially sustainable development. This research paper has a high relevance for other high-emigration economies.
\end{abstract}

Keywords: service marketing; brand awareness; trust; labour research; consumers; sustainable employment; social sustainability; Lithuania

\section{Introduction}

Brand is a key element of competitive advantage for service providers [1]. The brand name of a company and its visual presentation combined with promotional strategies and symbolic associations are the main elements of the brand [1]. Awareness of the company's name is the first step toward consumer-based brand equity building and consumers' choice [2]. The consumers first get to know the company's name, then the name forms the consumers' view on the image and the purpose of the company and its activities [1]. If someone knows the brand of the company and correctly assigns the company name to a certain category of services, he will probably become a customer of a company as well [3]. When consumers choose and evaluate products, brand awareness plays a critical role. Companies employ a "brand strategy" as their main focus to strengthen their positions in the market and to establish consumer loyalty to the brand.

For new and small businesses, brand awareness is crucial [4]. Well-known brands obtain consumer confidence, which allows consumers to take advantage of the known services of the company [5]. One of the strengths of a well-known brand is that it reduces the risk to consumers using an intangible product. Another advantage, from the perspective of a long-term business, is the fact that it creates a stable demand for service from the consumer side, which helps to increase the market share of the employment services. These benefits add value to the company's profitability, which may be the main goal of creating a brand awareness service [1]. 
Awareness is the first step toward the formation of brand equity. Awareness is the ability of consumers to recognize and to recall the particular product or service and to assign it to a particular category of products and services [6]. Brand recognition allows consumers looking for clearer clues to recognize the brand, and brand recall indicates that consumers are capable of recalling certain brands when provided with particular product or service categories, i.e., to recall a specific brand from their memories [7]. Companies seek the recognition of their brand, and this requires two elements: increasing the brand identity and linking features that relate to the brand with the company's services [8].

Brand awareness and trust are particularly relevant for the employment agency sector. While employment and sustainability are rarely related in research literature, labor-related factors are key drivers of a sustainable economy. Many recent technological developments and societal challenges provide opportunities for the redefining of work conditions and for access to more fair and equal work conditions [9]. Addressing the problem of unemployment is one of the main challenges of long-term sustainable development, especially considering youth unemployment [10] and the large amount of emigration in the Central European region.

Social sustainability includes several aspects, such as worker empowerment, economic growth, the reduction of poverty, and access to work [11]. Closely linked is the idea of corporate social sustainability (CSR) [12], which applies the aspects of social sustainability at a company level, therefore contributing to increased social sustainability at national and regional levels. On the other hand, companies see sustainability as a factor that allows for increased brand awareness and as having the potential to strengthen the status and image of a company both for consumers and against it competitors. Managing socially responsible relationships with consumers leads to the development of sustainability networks and to the creation of strong brands [13]. In aiming for sustainable development, employment agencies can be seen as first-order agents, which have direct influence and responsibility when implementing the goals of social sustainability. For example, they work to increase the awareness of people looking for a job, provide necessary skills for sustainable economics, and create partnerships between employment sector actors [14]. In fact, this increased awareness is seen as a fundamental component of sustainable development [15]. Furthermore, trust is an important mediating variable when considering consumer attitudes toward a corporation and its corporate reputation [16]. A sincere and trustworthy relationship between consumers and brands leads to an interactive relationship influencing consumer choices [17]. Trust as a factor also correlates well with success and transparency [18], key factors of sustainability. The employee's trust in an organization as their place of work may depend on safe working conditions. This may be revealed by the extent to which employees will want to remain in their current position in the labor market and in the future.

Therefore, the role of employment agencies as providers of a socially important service and in supporting sustainable employment is growing. Employment agencies are defined as intermediaries between employees and employers, who help employers find the right candidate for a job position and help employees to find an appropriate position. However, high competitiveness in the employment market (currently there are 250 public and private employment companies in Lithuania [19]) makes it more difficult to distinguish brands of employment agencies, especially when there is little investment in brand awareness. Furthermore, the employment industry sector is sometimes associated with unethical and dishonest behavior in the eyes of the consumers, which makes it difficult for new brand names to earn good reputations and trust from their customers.

There are several reasons for the alleged bad reputation of employment agencies in the region. Firstly, employment agencies are seen as a front-end of the employers aiming to offset work conditions and to reduce hourly payment rates, especially when low-skill workers are hired [20]. Furthermore, there is social stigma associated with the customers of the employment agencies as people who cannot find jobs by themselves. In some cases, this is supported by econometric evidence claiming that unemployed job seekers who use the services of a public employment agency have longer unemployment spells than others using alternative pathways to find work [21]. Also, recruitment agencies have been seen as having bias against minority and disadvantaged groups such as elderly 
people [22]. Understanding such factors is important when aiming to gain a competitive edge in the employment market and in contributing towards sustainable employment practices.

Here, we analyze the factors affecting brand awareness (one of the dimensions of brand equity) in the employment agency business sector and present an employment agency in Lithuania as a case study. We use this case study to show the importance of increasing social sustainability through brand awareness in the context of consumer mistrust, which is strong in this sector.

\section{Brand Awareness and Trust in the Service Industry}

In the service industry, the company name is a brand of its service [23]. The company brand helps consumers to create and share a common image of the company, which includes such factors as reliability, trustworthiness, reputation, quality, experience, consumer feedback and recommendations. Recently, more attention has been given to the brand service [23] and its consumer perception. Trust in consumer brand can serve as a mediator between consumer perception and brand reputation [16].

The brand is applied and valued differently in the service industry because of different service characteristics [24]. Four characteristics distinguish the product from the service [25]. The first characteristic is intangibility, which means that the service cannot be touched, tasted, or seen, contrary to the product. The second characteristic is inseparability, which means that the presentation and use of the service are carried out at the same time, opposite to those of the product. The third characteristic is heterogeneity, when the service is provided differently to each consumer, e.g., in the field of employment, each customer receives different employment service and conditions. The last characteristic is defined as maturity, i.e., the service, unlike the product, cannot be stored for later use, as it causes a supply and demand problem that can be very difficult to synchronize with a company. A service mark is more important than a product's brand, as consumers have no tangible attributes when evaluating and comparing a service with a product [25].

Prominent models, such as Brand Synthesis and Brand Awareness Model for brand awareness in the service sector [1], are aimed at exploring brand awareness through the product [5]. The most widely used is the brand model for the product [6]. Berry has adapted and upgraded a model that is tailor-made for the service sector and can measure company brand awareness through branded elements introduced by the company and by external service brand communication [1], which includes word of mouth and other external marketing activities.

The Brand Awareness Model in services emphasizes two factors: a company-provided service mark and external service brand communication [26]. Compared to the Brand Awareness Model in the product category [5], it has introduced two elements: product brand replication and recognition. However, different models are constructed for a product [6] and for a service [1]. The dimensions are similar because the prevailing factors that measure brand awareness through brand recognition and replication are created through the way a company presents its brand to consumers and how well consumers are able to remember the brand. The branding dimension introduced by the company is examined through the name of the company and the elements of advertising. The name of the company can reduce the risk for consumers when acquiring the service, as the first things they notice are external factors such as the company name and logotype [1]. When analyzing this factor, the respondents must spontaneously identify the brand category [27]. An effective company brand directly contributes to the company's reputation. It is important for the company to have some kind of association with the company services, such as being simple, distinctive, and easily recognizable [6]. After creating the awareness of the brand, the second step toward brand equity creation is the creation of associations in the minds of the consumers [28].

Advertising is a powerful weapon supported by marketing research that helps to determine which ads are effective for existing and potential clients of the company. As the behavior of the consumers changes on the basis of what is socially acceptable and evolving in their environment, it is important for the brand to adapt to this environment and advertise in the location and time where the company can reach its potential customers most effectively [6]. 
Consumer perception needs to be positive and coherent [24]. This is important because the same message should be disseminated through different communication channels in order to make a positive impact [29-31]. Advertising can be used to improve brand awareness, in relation to the service and service category [32]. More extensive investment in advertising leads to an increasing awareness of that company [33]. Responsiveness is a very powerful factor that influences consumer behavior [34], and more popular brands are more likely to enjoy positive feedback from consumers than nameless ones with little popularity $[35,36]$.

External brand communication (such as by fans of the brand) helps consumers to gather information about the company and its services [1]. Recommendations and company publicity, e.g., disseminated as articles in the media, are the most common forms of external branding. Consumers can start trusting the company as a result of the impression they have about the company not only from communications provided by the company, but also from the opinions of independent people [31]. Recommendations are the general assessment of consumers of the characteristics of the services [1]. Recommendations are more relevant in the context of services than goods [37]. It is more difficult to assess a product than a service, as it requires to obtain physical ownership of a product, therefore the consumer is more likely to rely on the experience of other consumers $[1,37]$. The consumers who use the service are considered as a more objective source of information [38].

Popular brand names help consumers to mitigate their cognitive risks and to form positive appraisals [39]. Brand awareness shows stronger links between brands and consumers' memories [40]. Such findings reflect consumer capability in discerning differences between brands, which indicates stronger connections or traces in consumer memories. Brand awareness is regarded as an approach for measuring the strength of the impression made in consumers' minds [41].

Brand awareness has an impact on consumer decisions, suggesting that brand awareness is often under consideration in decision-making [42]. Brand awareness may influence consumers' perceptions, attitudes, or even affect their decisions and brand loyalty [43], e.g., consumers hold positive attitudes towards unfamiliar products with high brand awareness. On the contrary, in the case of products with low brand awareness, extra information on this product type is required for assessment, because consumers are unfamiliar with the brand names.

The employment service sector is regarded rather negatively by consumers, because of a lack of trust and good reputation [31]. The employment sector has negative associations in the Lithuanian market, therefore publicity could increase consumer confidence in the sector and its services. Corporate visibility means controlling information to reach one or more audiences with the aim of influencing their decisions and opinions about the company or the company's brand [38]. Publicity in the media is often associated with positive attention, but media attention that would negatively influence consumer opinion is also common and cannot be controlled by the company $[38,44]$. It can however have a high impact on the attitudes towards the brand and on the service industry as a whole.

\section{Methodology}

\subsection{Research Question}

We formulated our research question as follows:

How to increase the awareness of X brand among potential users in the employment market?

\subsection{Research Method and Data Collection}

We have conducted a quantitative study to investigate the brand awareness impact on $X$ brand in the employment services market. We have selected the quantitative research study because it is reliable and objective, statistically substantiated by the essential features of the structured survey, and has less freedom of interpretation [45]. Our research is based on an online anonymous survey, in which respondents answered questions by expressing their opinions on brand awareness factors in the employment services market. The purpose of the survey was to determine whether the company's 
brand $\mathrm{X}$ was known by potential consumers, to investigate what elements of brand awareness are most important and could help increase the brand awareness of $X$ among potential clients in Lithuania, and to account for contextual issues related to the employment sector in general. The study was conducted in April 2017. The survey was published on the web platform www.apklausk.lt. The online survey was posted on Facebook in various employment-related groups: work abroad, looking for work, seasonal work, etc. The survey was filled by 183 respondents, of which the target audience of the survey was 111. Ethical standards were followed by conducting a survey, and permission was acquired from the company $\mathrm{X}$ to use the data for scientific purposes and for academic writing.

\subsection{Sampling}

The target audience of this study was Lithuanian residents who are qualified and unskilled workers, according to the Lithuanian Classifier of Professions. According to the statistics department, the population of skilled and unskilled workers in Lithuania in 2016 amounted to 536,100. To calculate the sample size of skilled and unskilled workers, we used the following formula:

$$
n=\frac{z_{\alpha / 2}^{2} \times N \times[\pi \times(1-\pi)]}{\varepsilon^{2} \times(N-1)+z_{\alpha / 2}^{2} \times[\pi \times(1-\pi)]}
$$

here $n$ is the sample size; $z_{\alpha / 2}$-the critical value of the standard distribution $=1.96$ with $95 \%$ reliability, $N$-the population size; $\pi-0,5, \varepsilon$ - the sampling error $5 \%$.

The preferred sample size calculated according to this formula, was 384 respondents.

\subsection{Research Instrument}

The questionnaire was developed based on the service dimensions of the brand model (Brand Awareness Model) [1] and other scientific sources. In the Brand Awareness Model, awareness is addressed through the service provided by the company's brand name and external brand communication. The questionnaire consisted of 19 questions, of which 17 were closed questions and 2 were open questions, and included general questions, approaches to the employment sector, and demographic and theoretical model questions.

The overview of the questions is presented in Table 1. The 1st, 2nd, 8th, 9th, 10th, 11th, 12th, and 13th, 14th and 15th questions were based on the Likert scale. The answer to the 6th question is binary (yes or no). In the 7th question, the awareness of the company " $\mathrm{X}$ " name is presented in the form of an open question in order to find out the respondents' opinion without providing immediate help. The 16th, 17th, and 18th questions examine the demographic characteristics of the respondents. The structure and validity of the questionnaire are presented in Table 1.

Table 1. Questionnaire.

\begin{tabular}{llcc}
\hline \multicolumn{1}{c}{ Research Question } & \multicolumn{1}{c}{ Factors } & Question No. & Source \\
\hline Getting to know potential users. & Introductory question & 1 & Authors \\
\hline $\begin{array}{l}\text { Evaluate which criteria are important for } \\
\text { consumers when choosing a recruiting company }\end{array}$ & $\begin{array}{l}\text { Criteria that influence the methodology of } \\
\text { consumer choice }\end{array}$ & 5 & Authors \\
\hline $\begin{array}{l}\text { Evaluate the relevance of the company X name and } \\
\text { the associations in the market for services and find } \\
\text { out the level of awareness of the brand " } X^{\prime}\end{array}$ & The method of delivery of the brand's delivery & $2-4,6-8$ & Adapted based on [45] \\
$\begin{array}{l}\text { Evaluate the importance of communication } \\
\text { channels and what communication channels } \\
\text { potential users use }\end{array}$ & Brand delivered methodology & $9-11$ & Adapted based on [46] \\
\hline $\begin{array}{l}\text { Evaluate potential employers' attitudes and } \\
\text { opinions about employment companies }\end{array}$ & Brand external communication methodology & $12-15$ & Adapted based on [47] \\
\hline Age, gender, vocational classifications & Demographic & $16-19$ & Authors \\
\hline
\end{tabular}




\subsection{Data Analysis Methods}

The collected data was processed using SPSS version 22.0 (IBM, Chicago, IL, USA), while the graphs were generated using MATLAB version 8.6.0.267246 (R2015b) (MathWorks, Inc., Natick, MA, USA), as well as an absolute (N) and relative (\%) frequency, and standard deviation (SD). The reliability of the data was evaluated using Cronbach's alpha, as well as a defined percentage (N), percentage, standard deviation (SN). A Normality test was performed that determined the normality of the questionnaire data, and a Spearman correlation analysis was applied in order to determine the relationship between variables. One-factorial dispersion analysis using ANOVA and the $t$-test were also performed, and the variables were compared between groups.

\section{Results}

After assessing the credibility of the independent variables in the questionnaire, Cronbach's alpha was 0.721 for the brand of the company and 0.774 for external brand communication. These indicators are shown in Table 2 for reliability between variables. Note that Cronbach's alpha was evaluated using the following rules of thumb: 0.9-excellent reliability, 0.8-good, 0.7-acceptable, 0.6-controversial, 0.5 - poor, and $<0.5$ - unacceptable reliability [48]. The survey can be considered as statistically reliable, since Cronbach's alpha was $>0.7$.

Table 2. Reliability.

\begin{tabular}{ccc}
\hline Variables & Conbach's Alpha & Value \\
\hline Brand of the company & 0.721 & Acceptable \\
External brand communication & 0.774 & Acceptable \\
\hline
\end{tabular}

Descriptive statistics indicated how many respondents answered the questions $(\mathrm{N})$, which was the highest and lowest rating on the Likert scale for brand dimensions. The average and the standard deviations were also calculated. The brand awareness of $X$ brand was examined through the brand provided by the company, i.e., the name of the company and its advertising, as well as by external brand communication, i.e., recommendations and brand awareness. These dimensions were considered important to understand the extent to which potential users were important. The branding dimension of the company was not missed, as all respondents answered all the questions asked. Questions of this dimension were presented on the Likert scale, with the lowest value given by the respondents as 1 , and the maximum value as 5, from the 5-item scale. In estimating the importance of the brand introduced to consumers, the average was 3.594, and the standard deviation was 1.056 . When analyzing the external dimension of the brand communication, the respondents answered 111 questions, the lowest value was 1 , the maximum was 5 . The average value was 4.261 , and the standard deviation was 0.805 (see Table 3).

Table 3. Descriptive statistics.

\begin{tabular}{cccccc}
\hline Variables & N & Min & Max & Mean & SN \\
\hline Company reputation & 111 & 1 & 5 & 4.360 & 0.817 \\
Brand introduced by the company & 111 & 1 & 5 & 3.594 & 1.056 \\
External brand communication & 111 & 1 & 5 & 4.261 & 0.805 \\
\hline
\end{tabular}

The normality test found that the correlation between variables was non-parametric, so the Spearman correlation was used, because it can be used for abnormal distributions. The values of the Spearman correlations are shown in Table 4 (all values are significant). To evaluate them, we used the following rules of thumb for the Spearman correlation: 0.90 to 1.00 - very high, 0.70 to 0.90 - high, 0.50 to 0.70 - moderate, 0.30 to 0.50 - low, 0.00 to 0.30 -little if any [49]. Therefore, we evaluated all correlations as moderate. 
Table 4. Spearman correlations.

\begin{tabular}{|c|c|c|c|}
\hline Variables & Company Reputation & Brand Introduced by the Company & $\begin{array}{l}\text { External Brand } \\
\text { Communication }\end{array}$ \\
\hline Company reputation & - & $0.587^{* *}$ & $0.515^{* *}$ \\
\hline Brand introduced by the company & $0.587^{* *}$ & - & $0.655^{* *}$ \\
\hline External brand communication & $0.515^{* *}$ & $0.655^{* *}$ & - \\
\hline
\end{tabular}

Regression analysis showed that all independent variables had a positive relationship with the company's reputation (see Table 5). External brand communication had the most significant impact on the company's reputation $(B=0.398, p=0.000)$, which indicated that if the external brand communication increased by 0.398 , then the awareness of the company would increase by one positive point. The brand provided by the company also had a rather significant impact on the company's reputation $(B=0.279, p=0.005)$, and if we increased the company's reputation by 0.279 , the company's awareness would increase in one positive point.

Table 5. Coefficients of the regression analysis.

\begin{tabular}{cccc}
\hline Dependant Variable & Independent Variables & $\boldsymbol{B}$ & Significance \\
\hline Company reputation $R^{2}=0.375$ & Brand introduced by the company & 0.278 & 0.005 \\
Significance $=0.000$ & External brand communication & 0.398 & 0.000 \\
\hline
\end{tabular}

Demographic issues. The survey included 56.8\% $(N=63)$ men and $43.2 \%(N=48)$ women. The distribution of the respondents was not the same for age groups (see Figure 1). Most respondents were in the age group from 18 to 28 years, $61.3 \%(N=68), 18 \%$ of the respondents were in the $29-38$ and $39-48$ years age groups $(N=20)$, and $2.7 \%(N=3)$ were in the $49-58$ years age group. A one-way ANOVA after a Bonferroni adjustment showed that there was a significant difference between age groups ( $p=0.000, \mathrm{~F}=15.633$ ) in brand awareness.

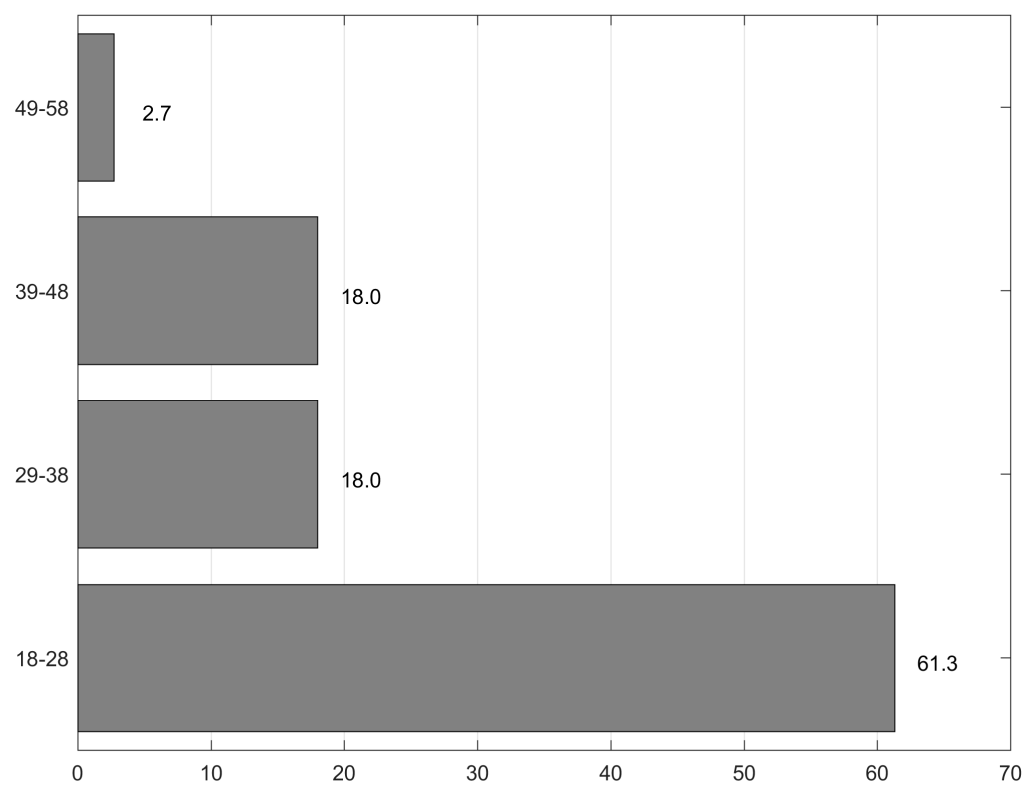

Figure 1. Distribution of age among the respondents.

The distribution of respondents by place of residence was recorded using the following three options: metropolitan area ( $>100,000$ inhabitants), city, and village ( $<7000$ inhabitants). Most of the respondents had their place of residence in the metropolitan area: $61.2 \%(N=68)$. A smaller proportion 
of the respondents came from a city, i.e., $37 \%(N=41)$, and the lowest number of respondents resided in a village, i.e., $1.8 \%(N=2)$ of all respondents.

The distribution of the respondents according to vocational classifications was as follows: skilled workers $68.5 \%(N=76)$, unskilled workers $31.5 \%(N=35)$ of all selected respondents.

The first question was introductory and asked, "How much trust do you have in recruiting agencies for recruiting abroad?" and aimed to identify the attitudes of the respondents and their confidence in recruiting agencies. After evaluating the answers of the respondents, 35\% $(N=19)$ were "lightly confident" in employment agencies that employ foreign workers. Slightly fewer respondents chose "Very Trustworthy" for employment agencies, i.e., 22\% $(N=24)$, and 17\% and 9\% of respondents indicated their mistrust in employment agencies that transfer people abroad ("I do not really believe" and "I do not trust", respectively). Gender analysis showed that there were no significant differences between the genders on the issue of trust in the employment agencies ( $t$-test results: $t=-0.080$, $\mathrm{F}=2.793, p=0.936$ ).

The fifth question dealt with the most relevant criteria for potential clients when dealing with an employment service company, and the answers were evaluated on a 5-item scale (1-“not at all important", 5-"very important"). While all criteria were quite important for potential users, the most important criteria distinguished the quality of the company services with a value of 4.76 , with $81.1 \%$ of respondents choosing the most important criterion. Another important criterion for the consumers was to get customer feedback from a company by choosing an employment service (78\%). The reputation of the company in the market was the most important for $73 \%$ of customers. The importance of a variety of job positions was the most important for $53 \%$ of consumers. However, all of the listed criteria were relevant to the respondents, since for all criteria the average value was higher than 4 points (see Figure 2).

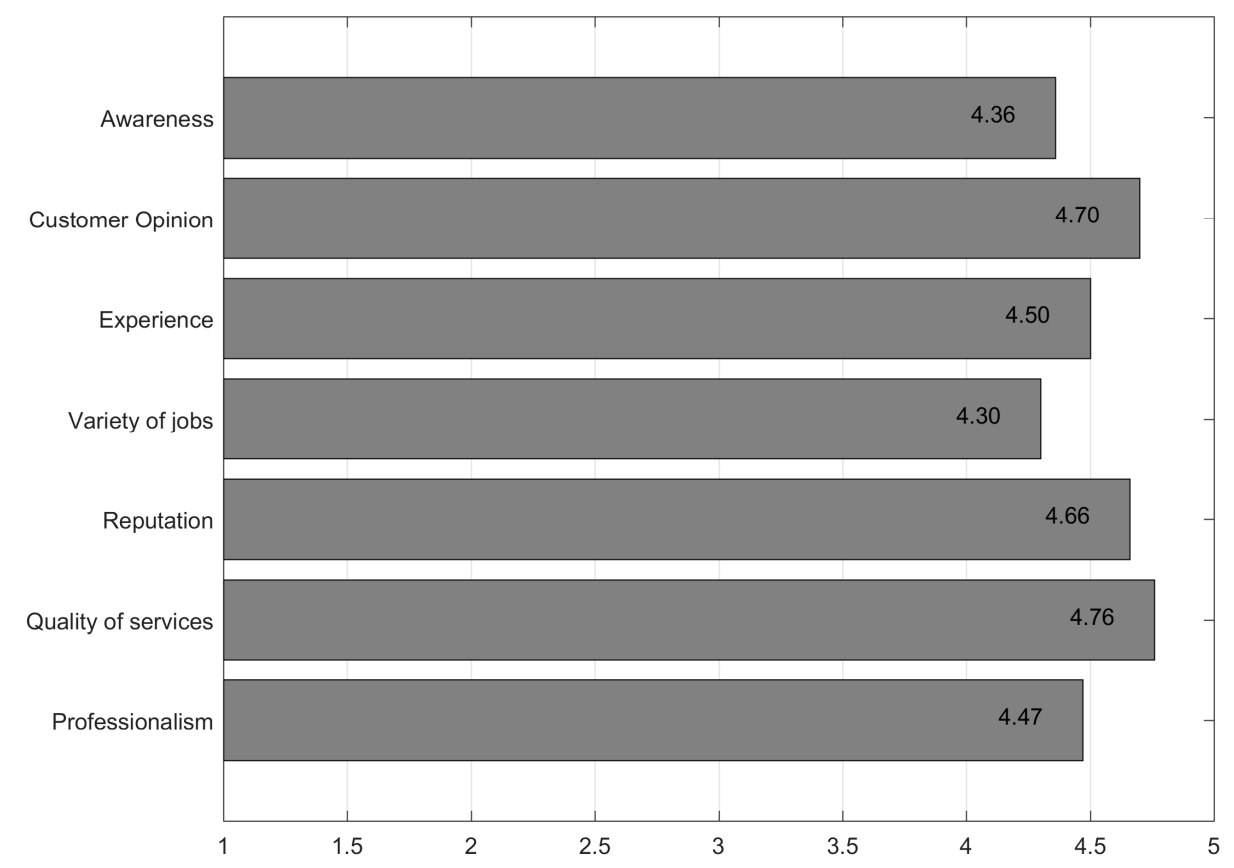

Figure 2. Mean importance of criteria in choosing an employment company.

Considering the awareness of $X$ brand among the potential customers, $26.8 \%$ of the respondents had heard of $X$, and $72.3 \%$ had not fully heard of this employment company. The gender analysis using the $t$-test showed no statistically significant differences between males and females $(\mathrm{F}=0.756$, $t=-0.439 \pm 0.02, p=0.387)$. 
With regard to the associations caused by the company brand name, $50 \%$ of respondents said $\mathrm{X}$ was associated with construction, 9.3\% thought it was related with employment, and the rest $40.7 \%$ said that it was not associated with any business type.

The evaluation of the attractiveness of the consumer advertisement showed that the most noticeable ads was Internet advertising (4.40 \pm 0.89$)$, followed by outdoor advertising (3.50 \pm 1.07$)$, television (TV) advertising (3.43 \pm 1.37$)$, and radio advertising (2.89 \pm 1.275$)$ (see Figure 3$)$.

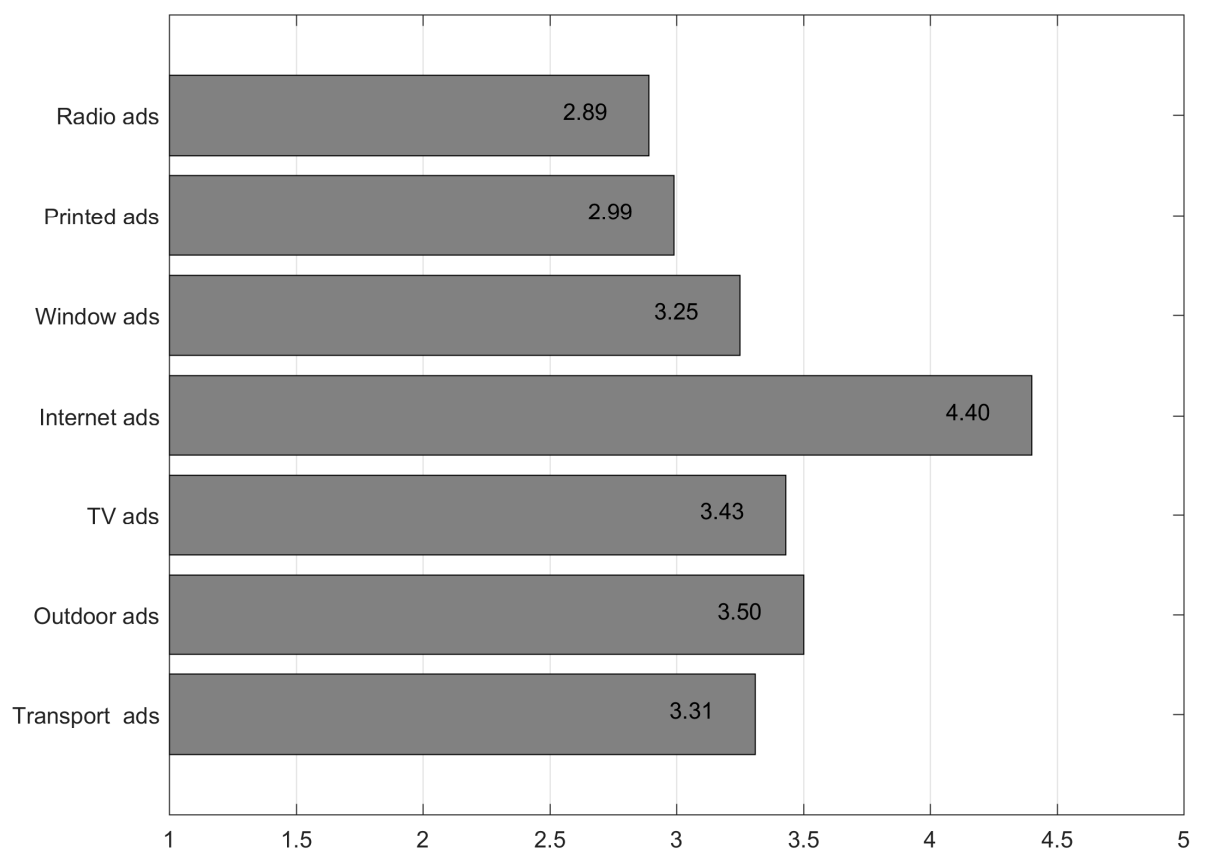

Figure 3. Mean attractiveness of consumer advertisements.

Gender analysis showed no statistically significant differences between males and females in the perception of Internet advertisements $(\mathrm{F}=1.879, t=-1.279 p=0.173)$, outdoor ads $(\mathrm{F}=0.799, t=0.318$, $p=0.373)$, and TV ads ( $\mathrm{F}=0.498, t=-1.869, p=0.482)$. Also, there were no statistically significant differences between age groups in their views regarding Internet advertising (using $t$-test; see Table 6) as well as in views regarding outdoor advertising (Tamhane's post-hoc: $p>0.005, \mathrm{~F}=0.792$ ) and TV ads (Tamhane's post-hoc $p>0.005, \mathrm{~F}=2.956$ ). Summarizing, we can claim that customer views on Internet, outdoor, and TV advertising do not depend on the age or gender of the customers.

Table 6. Differences in age groups in relation to Internet advertisements.

\begin{tabular}{ccccc}
\hline Age Groups & $\mathbf{1 8 - 2 8}$ & $\mathbf{2 9 - 3 8}$ & $\mathbf{3 9 - 4 8}$ & $\mathbf{4 8 - 5 9}$ \\
\hline \multicolumn{5}{c}{ Diagonal: Mean \pm standard deviation } \\
\hline & Other cells: $p$ value or $p$ is not statistically significant (NSS) \\
\hline $18-28$ & $2.647 \pm 1.243$ & $p=0.224$ & $p=0.693$ & $p=0.147$ \\
$29-38$ & $p=0.224$ & $3.450 \pm 1.356$ & NSS & NSS \\
$39-48$ & $p=0.693$ & NSS & $3.50 \pm 1.762$ & NSS \\
$48-59$ & $p=0.147$ & NSS & NSS & $4.333 \pm 0.577$ \\
\hline
\end{tabular}

The respondents were also asked about where they would go to search for a job if they needed it. The 5-item Likert scale was used from "definitely not" to "definitely yes". The respondents would definitely look for work through web portals for job advertisements (4.38 \pm 1.08$)$, social networks such as Facebook or LinkedIn $(3.50 \pm 1.46)$, online ads on dedicated web portals such as skelbiu.lt 
(3.35 \pm 1.50$)$, apply to the employment agency $(3.21 \pm 1.43)$, and look for work in newspaper ads $(2.68 \pm 1.48)$. See the results depicted graphically in Figure 4.

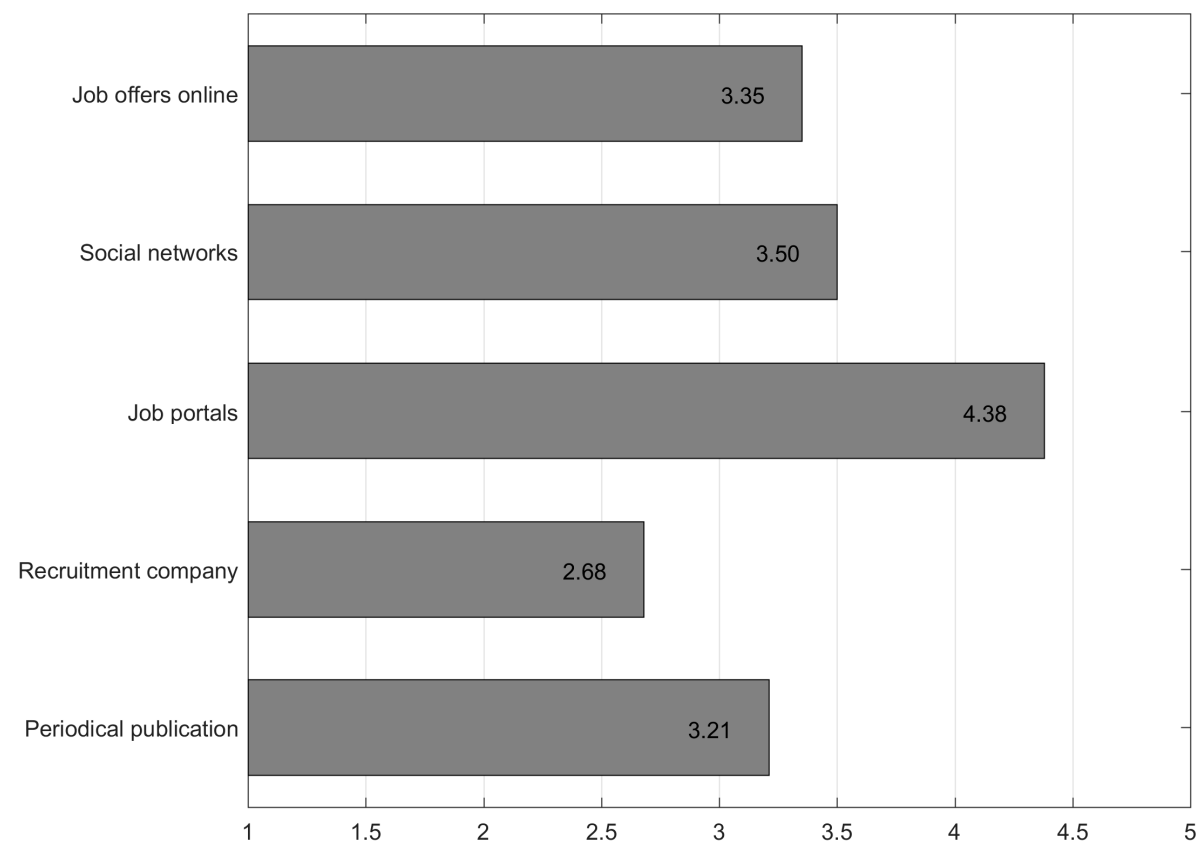

Figure 4. Strategies used by the respondents to apply or search if they need a job (mean values).

\section{Discussion and Conclusions}

Service companies create a strong brand through the brand's characteristics and message consistency to match their services, reaching consumers emotionally and assimilating the service's brand credibility [1]. A well-remembered company name and its advertisements directly link the user to the category of service that penetrates the consumer's emotional connection [50]. The employment industry sector is often associated with unethical and dishonest behavior in the eyes of the consumers, therefore there is a need for research that would contribute not only to the "adjustment" of the brand association, but also to the formation of greater confidence by promoting the main value of the company (the provision of high-quality services to its customers). The need for corporate social responsibility increases the role of a company's management in promoting sustainable leadership practices and increasing general sustainability awareness. That is, to be successful, companies must embed the principles of sustainability in the core of their strategy, services, and organizational culture. Trustworthiness, brand equity, and brand awareness are seen as some of the best mechanisms in achieving this aim [51]. Consumer trust is the key determinant of corporate capital that determines the potential and success of any sustainable organization [18] and creates valuable consumer-brand relationship. Building consumer trust can provide a competitive advantage for employment agencies [52].

Social media provide significant benefits to service brand development [53], as articles in social media aimed at the sharing of information through live chats, social networking, and online forums enhance a company's reputation and trust amongst its potential customers.

The recommendations of a company's existing customers are also important, because they allow the company to strengthen their brand in the market sector, which is not a fully developed market, especially in Lithuania, as the trust in employment enterprises is low because of the historically bad reputation of the sector [54]. Therefore, directed marketing actions can resolve consumer distrust of employment companies by improving their image and market visibility [55], thus contributing towards a vision of sustainable employment. 
Our empirical study shows that the reputation of $X$ employment company is most affected by the external brand communication, i.e., by word-of-mouth communication and publicity, which is an extension and/or consequence of brand communication. Increasing external brand communication would increase company awareness. Branding introduced by the company, i.e., the name and advertising, have slightly less influence, but they correlate with the company's reputation. When selecting an employment company, one of the most important criteria is the reputation of the company, therefore, it is beneficial to increase levels of trust in the employment company to improve the company's reputation. According to the respondents' answers, the most important criterions for choosing an employment company are the quality of services (4.76) and customer feedback from the company (4.7).

We found that $35 \%$ percent of respondents were "lightly confident" in employment agencies that employ foreign workers and just $9 \%$ of respondents said "I do not trust" the employment agencies. Another important result of our quantitative study is related to gender research: we found no statistically significant differences between males and females in their perception of trust in employment agencies, brand awareness, and the perception of Internet, outdoor, and TV advertisements. Such results are in contradiction with some other works (such as [56]), however the differences may be explained by other factors such as geographical region, cultural attitudes, and the topic of advertisement, which were not considered by the current study.

The limitations of the study are as follows. The size of the sample was smaller than recommended, which prevented the study from achieving more accurate results. As the $\mathrm{X}$ employment company targets specific customers (qualified and unskilled workers), it was difficult to reach the target audience using an Internet-based survey, therefore, there was a significant bias in the age of the respondents (more than half of the respondents (61.3\%) was in the 18-28 age group).

Author Contributions: Inga Minelgaite was involved in conceiving, designing and supervising the study it; Kristina Ročkute performed the experiments; Ligita Zailskaitė-Jakšte wrote the paper and prepared it for publication; Robertas Damaševičius revised and provided valuable comments. All authors participated in literature review research and preparation of the conclusions.

Conflicts of Interest: Kristina Ročkutè is actively involved in the employment/recruitment business. Other authors declare no conflicts of interest.

\section{References}

1. Berry, L.L. Cultivating Service Brand Equity. Acad. Mark. Sci. 2000, 28, 128-137. [CrossRef]

2. Keller, K.L. Strategic Brand Management; Pearson Education Limited: London, UK, 2013.

3. Keller, K.L. Strategic Brand Management: Building, Measuring, and Managing Brand Equity; Prentice Hall: Upper Saddle River, NJ, USA, 1998.

4. Aaker, D.A. Building Strong Brands; The Free Press: New York, NY, USA, 1996.

5. Keller, K.L. Brand synthesis: The multidimensionality of brand knowledge. J. Consum. Res. 2003, 29, 595-600. [CrossRef]

6. Keller, K.L. Conceptualizing, Measuring, and Managing Customer-Based Brand Equity. J. Mark. 1993, 57, 1-22. [CrossRef]

7. Zhou, T. Understanding users' initial trust in mobile banking: An elaboration likelihood perspective. Comput. Hum. Behav. 2012, 28, 1518-1525. [CrossRef]

8. Aaker, D.A. Managing Brand Equity: Capitalizing on the Value of a Brand Name. J. Mark. 1991, 56, 125-128.

9. Köves, A.; Király, G.; Pataki, G.; Balázs, B. Backcasting for Sustainable Employment: A Hungarian Experience. Sustainability 2013, 5, 2991-3005. [CrossRef]

10. Aceleanu, M.I.; Serban, A.C.; Burghelea, C. "Greening" the Youth Employment-A Chance for Sustainable Development. Sustainability 2015, 7, 2623-2643. [CrossRef]

11. Littig, B.; Griessler, E. Social sustainability: A catchword between political pragmatism and social theory. Int. J. Sustain. Dev. 2005, 8, 65-79. [CrossRef]

12. Jung, H.-J.; Ali, M. Corporate Social Responsibility, Organizational Justice and Positive Employee Attitudes: In the Context of Korean Employment Relations. Sustainability 2017, 9, 1992. [CrossRef] 
13. Teodorovic, M. Building strong brands in a modern sustainable environment. In Proceedings of the IAC-MEM 2015, Vienna, Austria, 10-11 July 2015.

14. Pociovălișteanu, D.M.; Novo-Corti, I.; Aceleanu, M.I.; Șerban, A.C.; Grecu, E. Employment Policies for a Green Economy at the European Union Level. Sustainability 2015, 7, 9231-9250. [CrossRef]

15. Mak, M.J.; Peacock, C.J. Social Sustainability: A Comparison of Case Studies in UK, USA and Australia. In Proceedings of the 17th Pacific Rim Real Estate Society Conference, Gold Coast, Australia, 16-19 January 2011.

16. Kim, H.; Hur, W.-M.; Yeo, J. Corporate Brand Trust as a Mediator in the Relationship between Consumer Perception of CSR, Corporate Hypocrisy, and Corporate Reputation. Sustainability 2015, 7, 3683-3694. [CrossRef]

17. Lee, S.H.E.; Workman, J.E.; Jung, K. Brand relationships and risk: Influence of risk avoidance and gender on brand consumption. J. Open Innov. Technol. Mark. Complex. 2016, 2, 14. [CrossRef]

18. Oláh, J.; Bai, A.; Karmazin, G.; Balogh, P.; Popp, J. The Role Played by Trust and Its Effect on the Competiveness of Logistics Service Providers in Hungary. Sustainability 2017, 9, 2303. [CrossRef]

19. Official Statistics Portal. Available online: https://osp.stat.gov.lt/web/guest/statistiniu-rodikliuanalize?portletFormName=visualization\&hash=ae0b1e97-010e-4f2b-8884-317f0010da83\# / (accessed on 1 January 2018).

20. Purcell, J.; Purcell, K.; Tailby, S. Temporary Work Agencies: Here Today, Gone Tomorrow? Br. J. Ind. Relat. 2004, 42, 705-725. [CrossRef]

21. Thomas, J.M. Public Employment Agencies and Unemployment Spells: Reconciling the Experimental and Nonexperimental Evidence. Ind. Labor Relat. Rev. 1997, 50, 667-683. [CrossRef]

22. Simning, A.; van Wijngaarden, E.; Conwell, Y. Overcoming Recruitment Barriers in Urban Older Adults Residing in Congregate Living Facilities. Psychiatry J. 2015, 2015, 824672. [CrossRef] [PubMed]

23. Berry, L.L. SERVQUAL: A multiple- Item Scale for measuring consumer perceptions of service quality. J. Retail. 1988, 12-40. [CrossRef]

24. Mackay, M.M. Application of Brand Equity Measures in Service Markets. J. Serv. Mark. 2001, 12, $210-221$. [CrossRef]

25. De Chernatony, L.; McDonald, M. Creating Powerful Brands in Consumer, Service and Industrial Markets; Butterworth-Heinemann: Oxford, UK, 1998.

26. Riezebos, R.; Riezebos, H.J.; Kist, B.; Kootstra, G. Brand Management: A Theoretical and Practical Approach; Pearson Education: London, UK, 2003.

27. Dabija, D.C.; Pop, M.C. Awareness-Indicator for Measuring the Equity of a Retail Brand. J. Int. Bus. Econ. 2008, 8, 54-61.

28. McDonald, M.H. Corporate Marketing and Service Brands-Moving beyond the fast-moving consumer products model. Eur. J. Mark. 2001, 35, 335-352. [CrossRef]

29. Zailskaitè-Jakštè, L.; Ostreika, A.; Jakštas, A.; Stanevičienè, E.; Damaševičius, R. Brand communication in social media: The use of image colours in popular posts. In Proceedings of the 40th International Convention on Information and Communication Technology, Electronics and Microelectronics (MIPRO), Opatija, Croatia, 22-26 May 2017; pp. 1373-1378.

30. Zailskaitè-Jakštè, L.; Damaševičius, R. Ontology of Brand Messaging Domain in Social Media Communication. In Proceedings of the European Conference on Social Media, ECSM 2014, Brighton, UK, 10-11 July 2014; pp. 584-593.

31. Zailskaite-Jakste, L.; Kuvykaitè, R. Communication in social media for brand equity building. Econ. Manag. 2013, 18, 142-153. [CrossRef]

32. Cobb-Walgren, C.J. Brand Equity, Brand Preference, and Purchase Intent. J. Advert. 1995, 24, 25-40. [CrossRef]

33. Yoo, D.N. An examination of selected marketing mix elements and brand equity. J. Acad. Mark. Sci. 2000, 20, 195-211. [CrossRef]

34. Fok, D.; Paap, R.; Franses, P.H. Incorporating Responsiveness to Marketing Efforts in Brand Choice Modeling. Econometrics 2014, 2, 20-44. [CrossRef]

35. Chou, H.Y.; Lien, N.H. What does a negative political ad really say? The effects of different content dimensions. J. Mark. Commun. 2011, 17, 281-295. [CrossRef]

36. Hsieh, Y.C.; Chen, K.H. How different information types affect viewer's attention on internet advertising. Comput. Hum. Behav. 2011, 27, 935-945. [CrossRef] 
37. Wirtz, J.; Chew, P. The effects of incentives, deal proneness, satisfaction and tie strength on word-of-mouth behaviour. Int. J. Serv. Ind. Manag. 2002, 13, 141-162. [CrossRef]

38. Grönroos, C. Service Management and Marketing-A Customer Relationship Management Approach; Wiley: Chichester, UK, 2000.

39. Johnson, S.K.; Podratz, K.E.; Dipboye, R.L.; Gibbons, E. Physical attractiveness biases in ratings of employment suitability: Tracking down the "beauty is beastly" effect. J. Soc. Psychol. 2010, 150, 301-318. [CrossRef] [PubMed]

40. Kuisma, J.; Simola, J.; Uusitalo, L.; Öörni, A. The effects of animation and format on the perception and memory of online advertising. J. Interact. Mark. 2010, 24, 269-282. [CrossRef]

41. Li, J.X.; Song, M.L. Try to Persuade Sentimentally or Rationally: The Choice of Advertising Appeals of Green Products. In Proceedings of the 2011 International Conference on Management and Service Science (MASS), Wuhan University, Wuhan, China, 12-14 August 2011; pp. 1-5.

42. Shahani-Denning, C.; Dudhat, P.; Tevet, R.; Andreoli, N. Effect of physical attractiveness on selection decisions in India and the united states. Int. J. Manag. 2010, 27, 37.

43. Strasser, A.A.; Tang, K.Z.; Romer, D.; Jepson, C.; Cappella, J.N. Graphic warning labels in cigarette advertisements: Recall and viewing patterns. Am. J. Prev. Med. 2012, 43, 41-47. [CrossRef] [PubMed]

44. Marconi, J. The Complete Guide to Publicity-Maximize Visibility for Your Product, Service, or Organization; NTC Business Books: Lincolnwood, IL, USA, 1999.

45. Buil, I.; de Chernatony, L.; Martínez, E. A cross-national validation of the consumer-based brand equity scale. J. Prod. Brand Manag. 2008, 17, 384-392. [CrossRef]

46. Holbrook, M.B.; Batra, R. Assessing the role of emotions as mediators of consumer responses to advertising. J. Consum. Res. 1987, 14, 404-420. [CrossRef]

47. Bansal, H.S.; Voyer, P.A. Word-of-mouth processes within a services purchase decision context. J. Serv. Res. 2000, 3, 166-177. [CrossRef]

48. George, D.; Mallery, P. SPSS for Windows Step by Step: A Simple Guide and Reference; Pearson Education: London, UK, 2003; Volume 11, pp. 20-52.

49. Hinkle, D.E.; Wiersma, W.; Jurs, S.G. Applied Statistics for the Behavioral Sciences, 5th ed.; Houghton Mifflin: Boston, MA, USA, 2003.

50. Weber, M. Essays in Sociology; Routledge: London, UK, 1970.

51. Linnenluecke, M.K.; Russell, S.; Griffiths, A. Subcultures and Sustainability Practices: The Impact on Understanding Corporate Sustainability. Bus. Strateg. Environ. 2009, 18, 432-452. [CrossRef]

52. Gefen, D.; Karahanna, E.; Straub, D.W. Trust and TAM in online shopping: An integrated model. MIS Q. 2003, 27, 51-91. [CrossRef]

53. Larsen, C.A.; Vesan, P. Public Employment Services, Employers and the Failure of Placement of Low-Skill Workers in Six European Countries; RECWOWE Publication, Dissemination and Dialogue Centre: Edinburgh, Scotland, 2011.

54. Burn, P. Entrepreneurship and Small Business. Start-up, Growth and Maturity, 4th ed.; PALGRAVE: London, UK, 2001.

55. Kanar, A.M.; Collins, C.J.; Bell, B.S. Changing an unfavorable employer reputation: the roles of recruitment message-type and familiarity with employer. J. Appl. Soc. Psychol. 2015, 45, 509-521. [CrossRef]

56. Yarahmadi, F. Perception Differences Towards TV Commercials: A Gender Comparison in Iran. Aust. J. Basic Appl. Sci. 2015, 6, 314-321.

(C) 2018 by the authors. Licensee MDPI, Basel, Switzerland. This article is an open access article distributed under the terms and conditions of the Creative Commons Attribution (CC BY) license (http://creativecommons.org/licenses/by/4.0/). 